\title{
The Prevalence of Cardiovascular Disease Risk Factors among Students of International Islamic University Malaysia, Kuantan Campus
}

\author{
Mukramah Binti Abdul Shomad ${ }^{1}$, Nor Azlina A. Rahman ${ }^{1 *}$, Nor Iza A Rahman ${ }^{2}$, Mainul Haque ${ }^{2}$ \\ ${ }^{1}$ Department of Biomedical Science, Kulliyyah of Allied Health Sciences, International Islamic University Malaysia, Kuantan Campus, Malaysia. ${ }^{2}$ Faculty \\ of Medicine, Universiti Sultan Zainal Abidin, 20400 Kuala Terengganu, Malaysia.
}

\section{ARTICLE INFO}

Article history:

Received on: 07/12/2015

Revised on: 12/01/2016

Accepted on: 29/01/2016

Available online: 30/03/2016

Key words:

Prevalence, risk factors,

CVD, diet, Physical activity.

\begin{abstract}
Cardiovascular disease (CVD) has become the leading cause of death among the non-communicable diseases worldwide. There are many contributing risk factors for the emergence of CVD. A cross-sectional study was conducted to observe the prevalence of CVD risk factors among International Islamic University Malaysia (IIUM) Kuantan Campus (KC) students. 156 participants from different faculties and years of study participated; among them 56 participants were able to complete the whole procedures. A set of questionnaires were distributed to participants. Anthropometric measurements, weight, height, waist circumference, random blood glucose (RBG) and blood pressure were measured. Prevalence of hypertension was $4 \%$. The mean systolic blood pressure (SBP) and diastolic blood pressure (DBP) was $114.268 \pm 12.034$ and $74.964 \pm 8.636$ of $\mathrm{mmHg}$ respectively. Prevalence of overweight and obesity was $34 \%$, with women having a higher percentage (21\%) than men (12\%). The mean Body-Mass Index (BMI) was $22.184 \pm 4.435 \mathrm{~kg} / \mathrm{m}^{2}$. The waist circumference has an average of 71.661 $\pm 9.215 \mathrm{~cm}$. Prevalence of high blood glucose was absent, and the mean blood glucose level was $6.007 \pm 1.018$ $\mathrm{mmol} / \mathrm{L}$. Dietary fibre-rich foods; vegetables were eaten 6-7 times per week, granola bars and fruits were eaten 12 times per week. Home cooked foods were taken 1-2 times per week. Fast foods were taken frequently around 35 times per week. The study community was engaged in physical activities such as brisk-walk, skipping and sports. Smoking prevalence was $4 \%$ only among the male population. The stress level was moderate. The students of IIUM KC practiced healthy diet and were physically active. The CVD-related risks do not prevail among the IIUM KC population.
\end{abstract}

\section{INTRODUCTION}

"CVDs are the number 1 cause of death globally: more people die annually from CVDs than from any other cause. An estimated 17.5 million people died from CVDs in 2012, representing $31 \%$ of all global deaths. Of these deaths, an estimated 7.4 million were due to coronary heart disease and 6.7 million were due to stroke. Over three-quarters of CVD deaths take place in low- and middle-income countries. Out of the 16 million deaths under the age of 70 due to noncommunicable diseases, $82 \%$ are in low and middle-income countries, and $37 \%$ are caused by CVDs. Most CVDs can be prevented by addressing

* Corresponding Author

Nor Azlina A. Rahman, Assistant Professor, Department of Biomedical Science, Kulliyyah of Allied Health Sciences, IIUM Kuantan Campus Malaysia.Email: nazara@iium.edu.my behavioral risk factors such as tobacco use, unhealthy diet and obesity, physical inactivity and harmful use of alcohol using population-wide strategies. People with CVD or who are at high cardiovascular risk (due to the presence of one or more risk factors such as hypertension, diabetes, hyperlipidemia or already established disease) need early detection and management using counseling and medicines, as appropriate." (WHO, 2015). CVD is a group of disorders of the heart and the blood vessels. This disorder includes coronary heart disease, cerebrovascular disease, peripheral artery disease, raised blood pressure, rheumatic heart disease, congenital heart disease and heart failure (WHO, 2015; Gaziano et al., 2006). They are commonly classified as a non-communicable disease. CHD is a condition where the walls of the coronary arteries, which supplies blood to the heart muscle become thickened and narrowed (Tortora et al., 2009). This resulted in insufficient blood supply to the myocardium, causing chest pain. 
The cerebrovascular disease involves the interruption of blood supply to the brain, resulting in a stroke. Loss of blood supply caused irreversible damage to the brain tissues (Tortora et al., 2009). The blockage commonly caused by the process of thromboembolism. Peripheral vascular disease affects the arteries supplying blood towards other regions of the body, apart from the myocardium and the brain (e.g. legs, hands, kidneys and other organs). The condition occurred when the arteries became narrowed due to atherosclerotic plaque, thus, limiting the blood supply to these organs.

The National Health and Nutrition Examination Survey of the United States conducted from the year 1999-2006 revealed that $59 \%$ of young adults had CVD associated with one or more of the CVD risk factors (Kuklina et al., 2010). The risk factors observed in the study include a family history of early CVD, smoking, hypertension, hypercholesterolemia, and obesity. Approximately $26 \%$ of the young adults showed an association of CVD with 2 or more risk factors and $12 \%$ of young adults with 1 risk factor of hypercholesterolemia (Kuklina et al., 2010). The Asia Pacific Cohort Studies Collaboration (APCSC) showed that hypertension, smoking, and diabetes mellitus were major risk factors for fatal and non-fatal stroke. It was observed that blood pressure is high, and hypertension is more prevalent in East Asia than in South Asia. It was reported that the population attributed fraction of hypertension for CVD is as high as 60\% in Asian countries.

The smoking rate for men in Asian countries in 2000 remains high at $40 \%$ to $60 \%$. Serum cholesterol level remains low for the Asian population, compared to the Western, but there is a high prevalence of glucose intolerance in the Western (Ueshima et al., 2008). A study conducted in a suburban area in Beijing found that the age-standardized prevalence of the CVD risk factors, overweight/obesity, diabetes, hypertension, dyslipidemia, and metabolic syndrome (MS) were 32\%, 6\%, 34\%, 31\%, and 12\% respectively (Zhang et al., 2010).

The prevalence of risk factors for CVD such as physical inactivity was $60 \%$, smoking $26 \%$, obesity $49 \%$, hypertension $26 \%$, raised blood glucose $11 \%$ and hypercholesterolemia $54 \%$ at Malaysia (Thon et al., 2012; Ghazali et al., 2015; MOH, 2010; Mustapha et al., 2014). Second National Health and Morbidity Survey in 1996 recorded a prevalence of $4 \%$ obese and 17\% overweight adults (MOH, 1996).

Subsequently, another a few research reported that the prevalence of overweight and obesity exists in both gender and equally observed in urban and rural areas (Khoo et al., 1997; Khor et al., 1999). There has three-fold from (4\% to 14\%) increase of obesity $2^{\text {nd }}$ and $3^{\text {rd }}$ national survey of Malaysia (IPH, 2008). Prevalence of the disease is increasing yearly, as well as many of the risk factors for the disease. Health monitoring of the public and community is extensively being done to study the conditions in order to control the up rise and prevent other health problems. Therefore, the current study was to determine the risk factors for CVD of students in IIUM KC and to study the diet and lifestyles that could lead to the emergence of CVD.

\section{MATERIALS AND METHODS}

The population selected for the project was students who were enrolled in the International Islamic University Malaysia (IIUM) of KC. All faculties existed in the Campus were involved. The faculties were Dentistry, Science, Medicine, Allied Health Sciences, Pharmacy and Nursing (Figure 1). The participants were selected following the eligibility criterion; inclusion criteria: students of IIUM KC, aged above 18 years old with no CVD, while exclusion criteria: pregnant mothers. The sample size of the sampling was determined beforehand. The confidence level $(Z)$ that has been chosen is $95 \%$, and $56 \%$ were determined for $p$ (propotion) as it was the percentages for good knowledge score among women in The North-East coast Malaysia (Rosediani, Ranimah, \& Harmy, 2012). To get manageable sample size, 0.08 precision has been chosen. The calculation above has yielded the sample size of 148. A $10 \%$ non-response rate is added to 148 . Therefore, the total respondents needed for this study is 163. A stratified random sampling was used whereby 35 names were randomly drawn from each faculty. A total of 210 names were available as future candidates for the study. The potential participants were traced for their whereabouts for recruitment into the project.

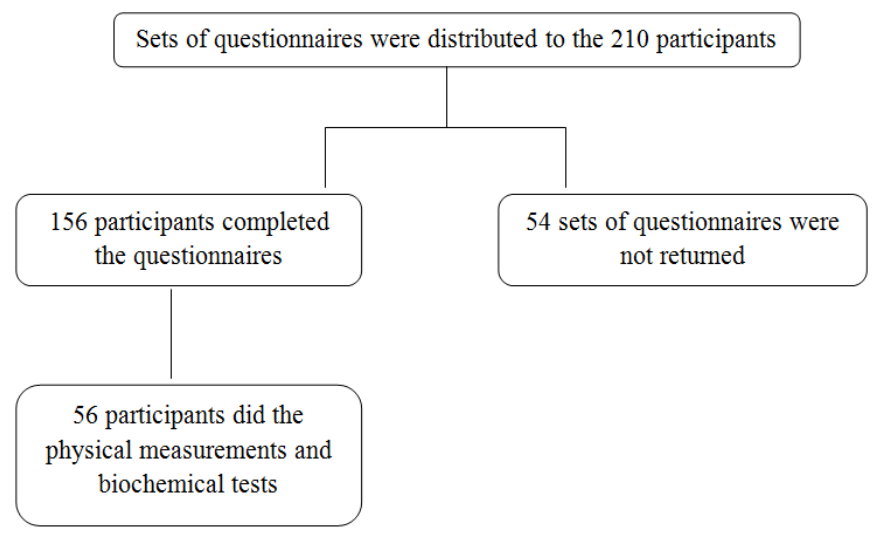

Fig. 1: Flow chart of response rate of the study.

A set of questionnaire was prepared. The questionnaire was developed into four sections: demographics, lifestyle, diet and physical activity. Section A was the demographic section. There were category questions of gender (male/female), faculties (Science, Dentistry, Medicine, Allied Health Sciences, Nursing and Pharmacy) and year of study (I-V). Section B was the lifestyle section. It consisted of listing or choice questions. There were questions about stress factors, smoking habit, and others. Section $\mathrm{C}$ was the diet section. It consisted of ranking or Likert scale based questions related to diet preferences. The frequency of food consumption was observed for either never/rare, seldom (1-2 times per week or less), numerous (3-5 times per week) and always (6-7 times per week or more). Lastly, section D was the physical activity section. It also consisted of ranking or Likert scale based questions related to physical activities. The frequency of physical activities performed were observed for either never/rare, seldom 
(1-2 times per week or less), numerous (3-5 times per week) and always (6-7 times per week or more). The weight and height of each participant were collected to determine the BMI. The weight measurement was obtained with a weight measuring scale. The participants were required to stand on the scale, and their weight was recorded. The height measurement was obtained after the participants had a stand in front of a measuring board. The BMI was calculated by dividing the weight (in $\mathrm{kg}$ ) by the square of height (in meters). The classification of BMI was based on the Strategy for the Prevention of Obesity-Malaysia (MASO, 2005) for Asian adults. A normal BMI will be 18.5 to 22.9 with the BMI of less than 18.5 is considered as underweight. Meanwhile, overweight was for BMI of 23 - 24.9 and those with BMI of 25 or more are considered as obese. The blood pressure measurements were conducted with a digital sphygmomanometer following the Clinical Practice Guidelines for Management of Hypertension (MOH, 2008). A measuring strip was used for the waist circumference for central obesity (MASO, 2005).

RBG measurement was done using the ACCUCHECK ${ }^{\circledR}$ glucometer (MOH, 2009). The participants were called to come for specific sessions scheduled for the test at the appointed venues. They were initially given a consent form for them to fill in. The signed consent form acknowledged their agreement to participate in the study. Participants were given the sets of questionnaires for them to complete.

After the questionnaires, the physical measurement, and biochemical test were done. All measurement data of participants were recorded, and they were referred to the set of questionnaires, which the participants had completed earlier. Data collected from the questionnaires, the physical measurements and test were entered into the SPSS software version 17. This study was approved as part of academic by the faculty of Allied Health Sciences, IIUM, Kuantan, Malaysia.

\section{RESULTS}

Out of 210 potential participants, 156 had answered the questionnaires giving the response rate of $74 \%$. 84 participants initially agreed to do the biochemical test and physical measurements. However, only $36 \%$ (56) participants were able to complete all the procedures. The participants consisted of $23 \%$ (36) males and $77 \%$ (120) females. The participants were from all six faculties in IIUM KC, and from Year-I to V (Table 1). Those who completed all the procedures were $25 \%$ (14) male and $75 \%$ (42) female participants. Among faculties and year of study, Dentistry $(22 \%)$ and Year-II was the highest (Figure 1). The average age of the total participants was $22.46 \pm 1.346$ years old.

The average weight and height of the test participants were $56.48 \pm 13.11 \mathrm{~kg}$ and $159.25 \pm 7.93 \mathrm{~cm}$ respectively. The BMI of the participants was $22.18 \pm 4.44$ suggesting the average BMI is normal. However, $34 \%$ of the participants were obese which is $50 \%$ and $29 \%$ from male and female respectively. $12 \%$ female and $7 \%$ male have high than normal waist circumference.

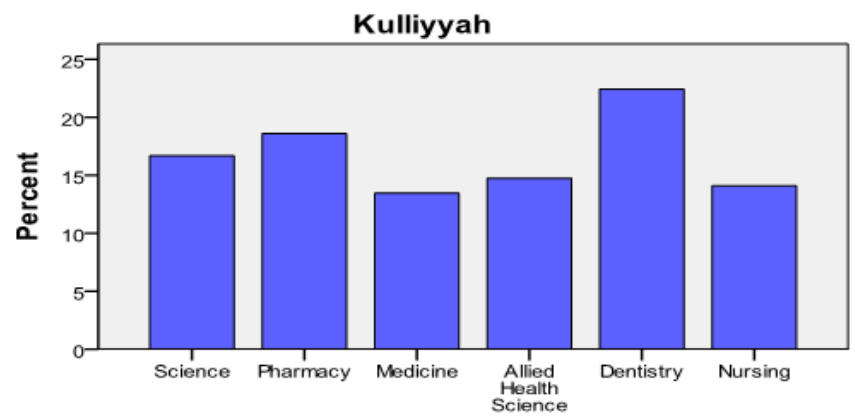

Fig. 2: Distribution of participants in different Faculty $(n=156)$

Table 1: Distribution of participants according to Faculty, year of study and age in different gender $(\mathrm{n}=156)$

\begin{tabular}{|c|c|c|c|}
\hline & \multicolumn{3}{|c|}{ Gender } \\
\hline & $\begin{array}{c}\text { Male } \\
(n=36)\end{array}$ & $\begin{array}{l}\text { Female } \\
(n=120)\end{array}$ & $\begin{array}{c}\text { Total } \\
(\mathrm{n}=156)\end{array}$ \\
\hline & $n(\%)$ & $n(\%)$ & $n(\%)$ \\
\hline \multicolumn{4}{|l|}{ Faculty } \\
\hline Science & $6(23.1)$ & $20(76.9)$ & $26(16.7)$ \\
\hline Pharmacy & $7(24.1)$ & $22(75.9)$ & $29(18.6)$ \\
\hline Medicine & $9(42.9)$ & $12(57.1)$ & $21(13.5)$ \\
\hline Allied Health Sciences & $6(26.1)$ & $17(73.9)$ & $23(14.7)$ \\
\hline Dentistry & $5(14.3)$ & $30(85.7)$ & $35(22.4)$ \\
\hline Nursing & $3(13.6)$ & $19(86.4)$ & $22(14.1)$ \\
\hline \multicolumn{4}{|l|}{ Year } \\
\hline I & $8(23.5)$ & $26(76.5)$ & $34(21.8)$ \\
\hline II & $10(22.7)$ & $34(77.3)$ & $44(28.2)$ \\
\hline III & $11(26.2)$ & $31(73.8)$ & $42(26.9)$ \\
\hline IV & $6(20.0)$ & $24(80.0)$ & $30(19.2)$ \\
\hline V & $1(16.7)$ & $5(83.3)$ & $6(3.8)$ \\
\hline \multicolumn{4}{|l|}{ Age } \\
\hline 20 & $1(16.7)$ & $5(83.3)$ & $6(3.8)$ \\
\hline 21 & $11(27.5)$ & $29(72.5)$ & $40(25.6)$ \\
\hline 22 & $7(20.0)$ & $28(80.0)$ & $35(22.4)$ \\
\hline 23 & $9(22.5)$ & $31(77.5)$ & $40(25.6)$ \\
\hline 24 & $6(25.0)$ & $18(75.0)$ & $24(15.4)$ \\
\hline 25 & $1(11.1)$ & $8(88.9)$ & $9(5.8)$ \\
\hline 26 & $1(50.0)$ & $1(50.0)$ & $2(1.3)$ \\
\hline
\end{tabular}

Table 2: Risk of CVD According to Gender $(n=56)$.

\begin{tabular}{|c|c|c|c|c|}
\hline & & $\begin{array}{c}\text { Male } \\
(n=14)\end{array}$ & $\begin{array}{c}\text { Female } \\
(n=42)\end{array}$ & $\begin{array}{c}\text { Total } \\
(n=56)\end{array}$ \\
\hline & Mean (SD) & $n(\%)$ & $n(\%)$ & $n(\%)$ \\
\hline Weight $(\mathrm{kg})$ & $56.48(13.11)$ & & & \\
\hline Height (cm) & $159.25(7.93)$ & & & \\
\hline BMI $\left(\mathrm{kg} / \mathrm{m}^{2}\right)$ & $22.18(4.44)$ & & & \\
\hline Normal & & $7(50.0)$ & $30(71.4)$ & $37(66.1)$ \\
\hline$>23.0$ & & $7(50.0)$ & $12(28.6)$ & 19 (33.9) \\
\hline SBP $(\mathrm{mmHg})$ & $114.27(12.03)$ & & & \\
\hline Normal & & $12(85.7)$ & $42(100.0)$ & $54(96.4)$ \\
\hline$\geq 140$ & & $2(14.3)$ & $0(0.0)$ & $2(3.6)$ \\
\hline DBP $(\mathrm{mmHg})$ & $74.96(8.64)$ & & & \\
\hline Normal & & $14(100.0)$ & $40(95.2)$ & $54(96.4)$ \\
\hline$\geq 90$ & & $0(0.0)$ & $2(4.8)$ & $2(3.6)$ \\
\hline $\begin{array}{l}\text { RBG RBG } \\
(\mathrm{mmol} / \mathrm{L})\end{array}$ & $6.01(1.02)$ & & & \\
\hline Normal & & $14(100.0)$ & $42(100.0)$ & $56(100.0)$ \\
\hline$\geq 11$ & & $0(0.0)$ & $0(0.0)$ & $0(0.0)$ \\
\hline Waist & $71.66(9.22)$ & & & \\
\hline \multicolumn{5}{|l|}{$\begin{array}{l}\text { Circumference } \\
(\mathrm{cm})\end{array}$} \\
\hline Normal & & $13(92.9)$ & $37(88.1)$ & $50(89.3)$ \\
\hline$\geq 80$ (female) & & - & $5(11.9)$ & $5(8.9)$ \\
\hline$\geq 90($ male $)$ & & $1(7.1)$ & - & $1(1.8)$ \\
\hline
\end{tabular}

The average waist circumference was $71.66 \pm 9.22 \mathrm{~cm}$. The average SBP and DBP was $114.27 \pm 12.03$ and $74.96 \pm 8.64$ $\mathrm{mmHg}$ respectively. The prevalence of hypertension was $4 \%$. 
Hypertension associated with SBP was seen in male (14\%) while for DBP was observed in female $(5 \%)$. The average RBG of the participants was $6.01 \pm 1.02 \mathrm{mmol} / \mathrm{L}$. No participant recorded having RBG measurement of higher than $10 \mathrm{mmol} / \mathrm{L}$ (Table 2). $89 \%$ and $88 \%$ of the participants took lunch and dinner respectively. It was then followed by breakfast $(64 \%)$; while brunch (24\%), high tea (13\%) and supper (27\%) (Table 3). This was seen true for both genders. Most of the participants $(43 \%)$ took three meals daily (Table 4).

Table 3: Distribution of participant's taking daily meals according to gender (n $=156$ ).

\begin{tabular}{|c|c|c|c|}
\hline & \multicolumn{2}{|c|}{ Gender } & \multirow[b]{2}{*}{$\begin{array}{c}\text { Total of taking the } \\
\text { meals }(n=156)\end{array}$} \\
\hline & $\begin{array}{c}\text { Male } \\
(n=36) \\
\end{array}$ & $\begin{array}{c}\text { Female } \\
(n=120)\end{array}$ & \\
\hline \multicolumn{4}{|l|}{ Meals } \\
\hline Breakfast & $15(15.2)$ & $84(84.8)$ & $99(63.5)$ \\
\hline Brunch & $10(26.3)$ & $28(73.7)$ & $38(24.4)$ \\
\hline Lunch & $32(23.0)$ & $107(77.0)$ & $139(89.1)$ \\
\hline High tea & $7(35.0)$ & $13(65.0)$ & $20(12.8)$ \\
\hline Dinner & $35(25.5)$ & $102(74.5)$ & $137(87.8)$ \\
\hline Supper & $11(26.2)$ & $31(73.8)$ & $42(26.9)$ \\
\hline
\end{tabular}

Table 4: The frequency of daily meals taken according to gender $(n=156)$.

\begin{tabular}{cccc}
\hline \multicolumn{3}{c}{ Gender } & \\
\hline & $\begin{array}{c}\text { Male } \\
(n=36)\end{array}$ & $\begin{array}{c}\text { Female } \\
(n=120)\end{array}$ & $\begin{array}{c}\text { Total } \\
(\mathrm{n}=156)\end{array}$ \\
\hline Times & $n(\%)$ & $n(\%)$ & $n(\%)$ \\
\hline 1 & $0(0.0)$ & $3(100.0)$ & $3(1.9)$ \\
2 & $14(31.1)$ & $31(68.9)$ & $45(28.8)$ \\
3 & $13(8.3)$ & $54(80.6)$ & $67(42.9)$ \\
4 & $5(17.2)$ & $24(82.8)$ & $29(18.6)$ \\
5 & $1(14.3)$ & $6(5.7)$ & $7(4.5)$ \\
6 & $3(60.0)$ & $2(40.0)$ & $5(3.2)$ \\
\hline
\end{tabular}

Table 5: Frequency of participants' daily food consumption $(\mathrm{n}=156)$

\begin{tabular}{|c|c|c|c|c|}
\hline & \multicolumn{4}{|c|}{ Percent (\%) } \\
\hline Male $(n=36)$ & Never/Rare ${ }^{\text {a }}$ & Seldom $^{\mathrm{a}}$ & Frequent ${ }^{\mathrm{a}}$ & Always ${ }^{a}$ \\
\hline \multicolumn{5}{|l|}{ Food type } \\
\hline Junk foods & 2.8 & 76.8 & 14.8 & 5.6 \\
\hline Nuts & 8.3 & 77.8 & 8.3 & 5.6 \\
\hline Granola bars & 36.1 & 61.1 & 2.8 & 0.0 \\
\hline Fruits & 2.8 & 72.2 & 19.4 & 5.6 \\
\hline Vegetables & 2.8 & 36.1 & 25.0 & 36.1 \\
\hline Grilled foods & 5.6 & 63.9 & 25.0 & 5.6 \\
\hline Steamed foods & 22.2 & 69.4 & 8.3 & 0.0 \\
\hline Boiled foods & 8.3 & 72.2 & 16.7 & 2.8 \\
\hline Fried foods & 16.7 & 63.9 & 5.6 & 13.9 \\
\hline Fast foods & 8.3 & 22.2 & 63.9 & 5.6 \\
\hline $\begin{array}{c}\text { Female } \\
(\mathrm{n}=120)\end{array}$ & Never/Rare ${ }^{a}$ & Seldom ${ }^{\text {a }}$ & Frequent $^{a}$ & Always ${ }^{a}$ \\
\hline \multicolumn{5}{|l|}{ Food type } \\
\hline Junk foods & 5.3 & 68.3 & 19.4 & 7.0 \\
\hline Nuts & 13.3 & 76.7 & 7.5 & 2.5 \\
\hline Granola bars & 50.0 & 44.2 & 5.0 & 0.8 \\
\hline Fruits & 1.7 & 60.8 & 20.8 & 16.7 \\
\hline Vegetables & 3.3 & 14.2 & 31.7 & 50.8 \\
\hline Grilled foods & 18.3 & 70.8 & 9.2 & 1.7 \\
\hline Steamed foods & 14.2 & 71.7 & 10.8 & 3.3 \\
\hline Boiled foods & 5.8 & 65.8 & 24.2 & 4.2 \\
\hline Fried foods & 17.5 & 45.8 & 5.0 & 31.7 \\
\hline Fast foods & 4.2 & 13.3 & 80.0 & 2.5 \\
\hline
\end{tabular}

" Bold words represent choices of highest frequency. ${ }^{\text {a Never/rare, seldom (1-2 }}$ times per week or less), frequent (3-5 times per week) and always (6-7 times per week or more).
Cooked foods (boiled, steamed, grilled and fried) were mostly eaten 1-2 times per week. $64 \%$ and $80 \%$ of male and female respectively disclosed have a tremendous fascination for junk foods and took 3-5 times per week. Snack foods comprise of chocolates, sweets, cakes, muffins, crackers, chips, etc. and were taken seldom (1-2 times per week or less) with male $(77 \%)$ and female $(68 \%)$. Nuts were taken seldom (1-2 times per week or less) by both genders. Men showed a higher preference for granola bars (energy bars) by taking them at 1-2 times per week while women showed preference of rare or never. $37 \%$ and $51 \%$ of male and female respectively showed a high preference for vegetables. However, fruits were taken at seldom (1-2 times per week) by both genders (Table 5).

Walking, at a brisk pace, was a frequent activity both for male $(36 \%)$ and female (43\%) and do 6-7 times per week or every day. General home exercise, which requires light or moderate effort, was frequently (3-5 times per week) done by both, male $(39 \%)$ and female (40\%). House chores done in the hostel were the least favorite activity by most participants. Moderate housework, a general household task requiring considerable effort, had only $50 \%$ of male and $35 \%$ of women who did it at seldom, 1-2 times per week or less. Aerobic exercise, hiking, and cycling were rated as the least favorite activities for both male and female. These activities required much effort thus making it the least ventured ones. However, most competitive sports were highly favored by both male $(33.3 \%)$ and female $(35.8 \%)$, despite requiring much effort comparable to the earlier three activities (Table 6).

Table 6: Various types of physical activities carried out by respondents $(\mathrm{n}=156)$.

\begin{tabular}{|c|c|c|c|c|}
\hline \multirow[b]{2}{*}{ Male $(n=36)$} & \multicolumn{4}{|c|}{ Percent $(\%)$} \\
\hline & Never/Rare ${ }^{a}$ & Seldom $^{a}$ & Frequent $^{\text {a }}$ & Always $^{a}$ \\
\hline \multicolumn{5}{|l|}{$\begin{array}{l}\text { Physical } \\
\text { activities }\end{array}$} \\
\hline Walking & 5.6 & 25.0 & 33.3 & 36.1 \\
\hline Hiking & 58.3 & 27.8 & 5.6 & 8.3 \\
\hline Aerobic & 41.7 & 25.0 & 19.4 & 13.9 \\
\hline Cycling & 55.6 & 27.8 & 11.1 & 5.6 \\
\hline Home exercise & 16.7 & 36.1 & 38.9 & 8.3 \\
\hline Housework & 16.7 & 50.0 & 30.6 & 2.8 \\
\hline Sports & 22.2 & 33.3 & 11.1 & 33.3 \\
\hline $\begin{array}{l}\text { Female } \\
(n=120)\end{array}$ & Never/Rare ${ }^{\text {a }}$ & Seldom $^{\text {a }}$ & Frequent $^{\text {a }}$ & Always $^{a}$ \\
\hline \multicolumn{5}{|l|}{$\begin{array}{l}\text { Physical } \\
\text { activities }\end{array}$} \\
\hline Walking & 3.3 & 29.2 & 25.0 & 42.5 \\
\hline Hiking & 56.7 & 34.2 & 5.0 & 4.2 \\
\hline Aerobic & 34.2 & 46.7 & 12.5 & 6.7 \\
\hline Cycling & 48.3 & 41.7 & 6.7 & 3.3 \\
\hline Home exercise & 7.5 & 30.8 & 40.0 & 21.7 \\
\hline Housework & 1.7 & 35.0 & 32.5 & 30.8 \\
\hline Sports & 38.3 & 35.8 & 15.0 & 10.8 \\
\hline
\end{tabular}

The stress level of the participants was relatively low for both male $(53 \%)$ and female $(58 \%)$ participants whereby they experienced it seldom (Table 7). $21 \%$ and $79 \%$ of male and female respectively thought that educational stress was the highest provider. This was followed by a friend, financial and family 
issues. Health also identified also cause of stress (Table 8 ). $3 \%$ of total participants were smokers, $14 \%$ of the male were smokers, and none was female. A parametric test of Independent t-test was done for SBP, DBP and waist circumference to compare the difference means between male and female. The results (Table 9) showed that there was no significant difference in DBP between male and female. On the other hand, SBP and waist circumference showed that there was a significant difference between male and female.

Table 7: Stress level of participants $(n=156)$.

\begin{tabular}{|c|c|c|c|c|}
\hline & \multicolumn{4}{|c|}{ Percent $(\%)$} \\
\hline & Never/Rare ${ }^{a}$ & Seldom $^{\text {a }}$ & Frequent $^{a}$ & Always $^{\text {a }}$ \\
\hline \multicolumn{5}{|l|}{ Stress } \\
\hline Male $(n=36)$ & 11.1 & 52.8 & 33.3 & 2.8 \\
\hline Female $(n=120)$ & 11.7 & $\mathbf{5 7 . 5}$ & 25.0 & 5.8 \\
\hline \multicolumn{5}{|c|}{$\begin{array}{l}\text { Bold numbers represent choices of highest frequency. }{ }^{\text {a }} \text { Never/rare, seldom (1- } \\
2 \text { times per week or less), frequent (3-5 times per week) and always (6-7 times } \\
\text { per week or more). }\end{array}$} \\
\hline \multicolumn{5}{|c|}{ Table 8: Factors that caused stress $(n=156)$. } \\
\hline \multicolumn{5}{|c|}{ Gender } \\
\hline & $\begin{array}{c}\text { Male } \\
(\mathrm{n}=36)\end{array}$ & $\begin{array}{l}\text { Female } \\
(\mathrm{n}=120)\end{array}$ & & $\begin{array}{l}\text { Cotal } \\
=156)\end{array}$ \\
\hline Stress & $n(\%)$ & $n(\%)$ & & $(\%)$ \\
\hline Friends & $26(24.3)$ & $81(75.7)$ & & $7(68.6)$ \\
\hline Family & $11(24.4)$ & $34(75.6)$ & & $(28.8)$ \\
\hline Study & $29(20.7)$ & $111(79.3)$ & & $(89.7)$ \\
\hline Health & $6(25.0)$ & $18(75.0)$ & & $(15.4)$ \\
\hline Money & $17(27.4)$ & $45(72.6)$ & & (39.7) \\
\hline
\end{tabular}

Table 9: The comparison of risks of CVD between genders $(n=56)$.

\begin{tabular}{|c|c|c|c|}
\hline & Male & Female & \\
\hline & $\begin{array}{c}(n=14) \\
\operatorname{Mean}(S D)\end{array}$ & $\begin{array}{c}(n=42) \\
\text { Mean (SD) }\end{array}$ & $p$-value \\
\hline Weight (kg) & $61.65(24.1)^{\mathrm{c}}$ & $52.60(11.5)^{\mathrm{c}}$ & $0.006^{\mathrm{b}}$ \\
\hline Height (cm) & $167.50(13.3)^{\mathrm{c}}$ & $158.00(8.3)^{\mathrm{c}}$ & $<0.001^{\mathrm{b}}$ \\
\hline BMI $\left(\mathrm{kg} / \mathrm{m}^{2}\right)$ & $22.90(6.1)^{\mathrm{c}}$ & $21.05(4.7)^{\mathrm{c}}$ & $0.455^{\mathrm{b}}$ \\
\hline SBP (mmHg) & $124.07(11.23)$ & $111.00(10.51)$ & $<0.001^{\mathrm{a}}$ \\
\hline DBP $(\mathrm{mmHg})$ & 77.07 (7.60) & $74.26(8.93)$ & $0.296^{\mathrm{a}}$ \\
\hline RBG $(\mathrm{mmol} / \mathrm{L})$ & $5.55(1.6)^{\mathrm{c}}$ & $5.95(1.3)^{\mathrm{c}}$ & $0.902^{\mathrm{b}}$ \\
\hline $\begin{array}{l}\text { Waist Circumference } \\
(\mathrm{cm})\end{array}$ & $77.57(9.04)$ & $69.69(8.49)$ & $0.005^{\mathrm{a}}$ \\
\hline
\end{tabular}

The SBP had a moderate magnitude of difference in the means (mean difference $=13.071,95 \% \mathrm{CI}$ : 6.5 to 19.7 ). The waist circumference had a moderate magnitude of difference in the means (mean difference=7.881, 95\% CI: 2.5 to 13.2). As of weight, height, BMI, and RBG, a non-parametric Mann-Whitney test was done to compare the difference means between male and female. The $p$-value for BMI and RBG was more than 0.05 . There was a no significant difference in these variables between male and female. On the other hand, calculation of Mann-Whitney test of weight and height yielded $p$-value less than 0.05 , indicating a significant difference between male and female for the weight and height means.

\section{DISCUSSION}

The risk factors that were measured include diet, lifestyle, blood pressure, blood glucose, smoking, and BMI. The average values generated from all the variables showed a normal range of all variables. This indicated that the participants of this study had normal BMI, blood pressure, waist circumference and blood glucose level. The age expected disease prevalence for CVD was above 35 years old. Much of the risk associated with CVD such as hypertension and obesity became more prominent as someone entered the middle age. Most of the people who didn't take much care of their health when they were younger, in the 20 's, would develop much of the related risk conditions as they entered the middle age. A number of studies reported that CVD prevalence increases with the increasing age (Al-Alwan et al., 2013; Petoumenos et al., 2014; Peker et al., 2002). Another study reported that, with increasing age there was a gradual shift for DBP to SBP as a predictor of CHD risk (Franklin et al., 2001). The risk predictors increased at the age of 40 . The predictors became more prominent within the age of 50-60 years old. The overall prevalence of blood pressure in hypertensive range for the study participants was $4 \%$ which is comparable to another Malaysian study reported $4.5 \%$ and of <39 years old (Cheah, 2011). The current study test participants were calculated among 20 to 26 years old.

The obesity prevalence was $40 \%$ among the study participants. It was observed that male $(50 \%)$ had a higher prevalence than female (29\%). But earlier study found that obesity was $13 \%$ in young adults aged $<39$ (Cheah, 2011). The sample size $(n=238)$ of the earlier study mentioned was larger than the current study ( $n=56)$ which might yield a more reliable statistical calculation (Cheah, 2011). The waist circumference was a mean of $71.66 \pm 9.22 \mathrm{~cm}$. This value was far from the risk indication. There was zero prevalence of high blood glucose seen among study participants. All recorded RBG lied within the normal range. The average RBG for the test participants was $6.01 \pm 1.02 \mathrm{mmol} / \mathrm{L}$. There was a prevalence of $10 \%$ of high blood glucose among young adults (Cheah, 2011). This project managed to gather only a small number of participants to do the test. It couldn't be assumed that the results collected from this project presented the overall population of students in IIUM KC. There was an unequal distribution of male and female participants which may affect the results. The statistical information could moderately give an assumption of the overall population.

A higher percentage of the total participants enjoyed having 3 meals per day which consisted of breakfast, lunch and dinner. Practically, this is common among Malaysians. Generally, people eat whenever they feel hungry, or they just eat because they love to do it. People do not need a schedule to remind them when they need to eat, but it is a natural biological urge that involves complex mechanism. Another study conducted in Selangor, Malaysia also revealed similar findings of eating schedule (Karim and Mydenkather, 2003). The participants enjoyed various types of food. The food consumption usually depends on the knowledge and the workloads per day. Home prepared foods were usually healthy contain less salt and fat as compared to junk foods. The British Nutrition Foundation reported that energy-dense diets provide significant energy density which may be considered as an 
important factor for the likelihood of overconsumption leading to weight gain (Prentice et al., 2003). The majority of the participants irrespective of gender showed strong likeness for fast foods despite having knowledge. The additional and modified taste of some of these fast foods could become addictive. There is a need to continuously monitor the preparation method and hygiene for safe consumption by the authorities.

Food containing dietary fibers has been shown to lower plasma total and LDL-cholesterol (Truswell, 2002; Narayan et al., 2014; Wagner et al., 2008). Foods such as fruits, vegetables, whole-grain cereals, whole meal bread and soya contain precious fibers that could help digestion, gut motility and also lowers the risk of CVD. Fruits and vegetables contain vitamins and minerals, which improves all physiological functions. Eating nuts were also associated with a decreased likelihood of CHD (Ros, 2010; Good et al., 2009). A review of epidemiological studies involving five large cohort studies revealed that nuts once per week decreased risk for CHD (Kris-Etherton et al., 2001). The current study participants fruits and vegetable intake were high for both genders. They took vegetables more often with six to seven times per week compared to fruits at one to two times per week or less. One nutritional study reported that $78 \%$ and $75 \%$ men and women, respectively vegetables regularly, but regarding everyday fruits consumption women (46\%) were little higher than men $(38 \%)$ (Karim and Mydenkather, 2003). However, more than 50\% of our respondents' of both genders ate fruits, at least 1-3 times per week to 4-5 times per week. A good percentage of participants took fiber-rich foods such as nuts and granola bars. Junk foods had little or no nutritional value, but contained added sweeteners and preservatives. A healthy alternative for snacking could be substituted for fruits and vegetables, such as, apples and baby carrots which are delicious and nutritious. Granola bars and nuts were other healthy alternatives for snacking with additional benefits of lowering risk for CHD.

Active individuals have a lower risk to develop CVD compared to physically-inactive individuals (Wannamethee and Shaper, 2001). Brisk walking and regular vigorous exercise were associated with 30-40\% of reduction of coronary events by (Manson et al., 1999). Physically activity increases HDL cholesterol and decreases triglycerides concentration; on the other hand reduces CVD (Hardman, 1999).

A good proportion of respondents walk at a brisk pace regularly. Female participants were more active than man as most of the women walk daily to attend classes at IIUM. General home exercise, such as skipping, requires moderate effort and a good fun. Most of the participants of both genders regularly practice exercise at home. Moderate house chores were least favorite activities among the participants. Activities such as cycling, aerobics and hiking were activities that required much effort. They were done rarely but prove to be advantageous to keep one fit. Other competitive sports were highly favored despite the considerable and much effort expended over it. Sport is an enjoyable activity and makes the individuals become active. Smoking prevalence among the participants was about $3 \%$ and exclusively there were males. Cessation of smoking could affect the emerging risk factor for the improvement of arterial endothelium-dependent acetylcholine relaxation (Unverdorben et al., 2009). Stress could be attributed to risk to CVD although weakly associated (Macleod et al., 2002). The level of stress reported by the participants' project was moderate. Despite the possibility of having stress, they were able to overcome the stress causing problems by engaging in other beneficial activities i.e. praying, meeting with friends, sleep, eat, exercise and others.

\section{CONCLUSION}

The prevalence of overweight/obesity, high abdominal fats and hypertension was found to be low. There was zero prevalence of high blood glucose level. All calculated variables of BMI, blood pressure, RBG and waist circumference measurement indicated an average level. Healthy food intake was high. Fats and salts intake was also high while junk foods are moderate. The participants were shown to be physically active as they are seen engaged in various types of activities. Prevalence of smoking was low while the stress level was moderate.

It could be concluded that IIUM KC students have a low prevalence towards the risk of CVD. Participants are highly active and consumed healthy and balanced diet. The current study was cross-sectional and with limited sample size. Therefore, well designed prospective study is advocated to obtain more reliable data and ensure better health care among Malaysian citizen.

\section{ACKNOWLEDGEMENT}

Authors were much grateful to all students who participated in this study. Moreover, authors were very thankful to the IIUM authority to give permission and cooperation to conduct the study.

\section{REFERENCES}

Al-Alwan I, Badri M, Al-Ghamdi M, Aljarbou A, Alotaibi H, Tamim H. Prevalence of Self-reported Cardiovascular Risk Factors among Saudi Physicians: A Comparative Study. Int J Health Sci (Qassim). 2013; 7(1): 3-13.

Cheah WL, Lee PY, Khatijah Y, Rasidah AW. A Preliminary Study on the Prevalence of Cardiovascular Disease Risk Factors in Selected Rural Communities in Samarahan and Kuching Division, Sarawak, Malaysia. Malays J Med Sci. 2011; 18 (2): 58-65.

Franklin SS, Larson MG, Khan SA, Wong ND, Leip EP, Kannel WB, Levy D. Does the Relation of Blood Pressure to Coronary Heart Disease Risk Change with Aging? The Framingham Heart Study. Circulation. 2001; 103 (9): 1245-1249.

Gaziano T, Reddy KS, Paccaud F, Hortan S, Chaturvedi V. Cardiovascular Disease. In: Jamison DT, Breman JG, Measham AR, Alleyne G, Claeson M, Evans DB, Jha P, Mills A, Musgrove P. et al., editors. Disease Control Priorities in Developing Countries. 2nd edition. Washington (DC): World Bank; 2006. Chapter 33.Available at: http://www.ncbi.nlm.nih.gov/books/NBK11767/ [Accessed on 14 October 2015].

Ghazali SM, Seman Z, Cheong KC, Hock LK, Manickam M, Kuay LK, Yusoff AF, Mustafa FI, Mustafa AN. Sociodemographic factors associated with multiple cardiovascular risk factors among Malaysian adults. BMC Public Health. 2015; 15: 68. 
Good D, Lavie CJ, Ventura HO. Dietary Intake of Nuts and Cardiovascular Prognosis Ochsner J. 2009; 9(1): 32-36.

Hardman AE. Interaction of physical activity and diet: implications for lipoprotein metabolism. Public Health Nutr. 1999; 2 (3A): 369-376.

Institute of Public Health (IPH). Nutritional Status (The Third National Health and Morbidity Survey 2006). Kuala Lumpur, Malaysia: Ministry of Health Malaysia; 2008

Karim NA, Mydenkather H. Nutritional status and food habit of middle-aged adults in selected areas of Selangor. Malays J Nutr. 2003; 9(2): $125-136$

Khoo KL, Tan H, Liew YM. Serum Lipids and their Relationship with other Coronary Risk Factors in Healthy Subjects in a City Clinic. Med J Malaysia. 1997; 52(1):38-52.

Khor GL, Azmi MY, Tee ES, Kandiah M, Huang MSL. Prevalence of overweight among Malaysian adults from rural communities. Asia Pacific J Clin Nutr. 1999; 8 (4):272-279.

Kris-Etherton PM, Zhao G, Binkoski AE, Coval SM, Etherton TD. The effects of nuts on coronary heart disease risk. Nutrition Reviews. 2001; 59 (4): 103-111.

Kuklina EV, Yoon PW, Keenan NL. Prevalence of Coronary Heart Disease Risk Factors and Screening for High Cholesterol Levels among Young Adults, United States, 1999-2006. Ann Fam Med. 2010; 8 (4): 327-333

Macleod J, David Smith G, Heslop P, Metcalfe C, Carroll D, Hart C. Psychological stress and cardiovascular disease: Empirical demonstration of bias in a prospective observational study of Scottish men. BMJ. 2002; 324 (7348): 1247-1251.

Malaysian Association for the Study of Obesity (MASO). 2005. Strategy for the Prevention of Obesity-Malaysia. Malaysian Association for the Study of Obesity, Kuala Lumpur, Malaysia.

Manson JE, Hu FB, Rich-Edwards JW, Colditz GA, Stampfer MJ, Willett WC, Speizer FE, Hennekens CH.. A prospective study of walking as compared with vigorous exercise in the prevention of CHD in women. N Engl J Med. 1999; 341 (9): 650-658.

Ministry of Health (MOH). 2010. National Strategic Plan for Non-Communicable Diseases (NSPNCD). Non-Communicable Disease Section. Disease Control Division. 62590 Putra Jaya, Malaysia.

Ministry of Health Malaysia (MOH). 1996. Report of the Second National Health and Morbidity Survey. Kuala Lumpur: Institute of Public Health, Kuala Lumpur, Malaysia.

Ministry of Health Malaysia (MOH). 2008. Clinical Practice Guidelines for Management of Hypertension, $3^{\text {rd }}$ Edition. Kuala Lumpur, Malaysia.

Ministry of Health Malaysia (MOH). 2009. Clinical Practice Guidelines on Management of Type 2 Diabetes Mellitus, $4^{\text {th }}$ Edition. Kuala Lumpur, Malaysia.

Mustapha FI, Omar ZA, Mihat O, Noh KN, Hassan N, Bakar RA, Manan AA, Ismail F, Jabbar NA, Muhamad Y, Rahman LA, Majid FA, Shahrir SN, Ahmad E, Davey T, Allotey P. Addressing noncommunicable diseases in Malaysia: an integrative process of systems and Community. BMC Public Health 2014, 14(Suppl 2):S4

Narayan S, Lakshmipriya N, Vaidya R, Bai MR, Sudha V, Krishnaswamy K, Unnikrishnan R, Anjana RM, Mohan V. Association of dietary fiber intake with serum total cholesterol and low density lipoprotein cholesterol levels in Urban Asian-Indian adults with type 2 diabetes. Indian J Endocrinol Metab. 2014; 18(5): 624-630.
Peker Y, Hedner J, Norum J, Kraiczi H, Carlson J. Increased incidence of cardiovascular disease in middle-aged men with obstructive sleep apnea: a 7-year follow-up. Am J Respir Crit Care Med. 2002; 166(2):159-65.

Petoumenos K, Reiss P, Ryom L, Rickenbach M, Sabin CA, ElSadr W, d'Arminio Monforte A, Phillips AN, De Wit S, Kirk O, Dabis F, Pradier C, Lundgren JD, Law MG; D:A:D study group. Increased risk of cardiovascular disease (CVD) with age in HIV-positive men: a comparison of the D: A: D CVD risk equation and general population CVD risk equations. HIV Med. 2014; 15(10):595-603.

Prentice AM, Jebb SA. Fast foods, energy density, and obesity: a possible mechanistic link. Obes Rev. 2003; 4 (4): 187-194. 2(7): 652-682.

Ros E. Health Benefits of Nut Consumption. Nutrients. 2010;

Rosediani M, Ranimah Y, Harmy MY. Knowledge, Attitude and Practice on Cardiovascular Disease among Women in North-Eastcoast Malaysia. International Journal of Collaborative Research on Internal Medicine \& Public Health. 2012; 4 (1): 84-98.

Thon CC, Yein LP, Lian CW. The Prevalence of Cardiovascular Risk Factors in the Young and Middle-Aged Rural Population in Sarawak, Malaysia. Malays J Med Sci. 2012; 19(2): 27-34.

Tortora G, Derrickson B. 2014. Principles of Anatomy and Physiology. $14^{\text {th }}$ Edition, John Willey \& Sons. 111 River Street, Hoboken, NJ 07030-5774, USA.

Truswell AS. Cereal grains and coronary heart disease. Eur J Clin Nutr. 2002; 56 (1): 1-14.

Ueshima H, Sekikawa A, Miura K, Turin TC, Takashima N, Kita Y, Watanabe M, Kadota A, Okuda N, Kadowaki T, Nakamura Y, Okamura T. Heart Disease in Asia: Cardiovascular Disease Risk Factors in Asia. Circulation. 2008; 118 (25): 2702-2709.

Unverdorben M, von Holt KV, Winkelmann BR. Smoking and atherosclerotic cardiovascular disease: Part 2: Role of cigarette smoking in cardiovascular disease developments. Biomarkers Medicine. 2009; 3 (5): 616-653

Wagner EM, Jen K-LC, Artiss JD, Remaley AT. Dietary alphacyclodextrin lowers LDL-C and alters plasma fatty acid profile in LDLrKO mice on a high-fat diet. Metabolism. 2008; 57(8): 1046-1051.

Wannamethee SG, Shaper AG, Alberti KG. Physical activity, metabolic factors and the incidence of coronary heart disease and type 2 diabetes mellitus. Arch Int Med. 2000; 160 (14): 2108-2116.

World Health Organization (WHO). Cardiovascular diseases. Fact sheet $\mathrm{N}^{\circ} 317.2015 .2$ Available at: http://www.who.int/mediacentre/factsheets/fs317/en/ [Accessed on 14 November 2015]

Zhang L, Qin LQ, Liu AP, Wang PY. Prevalence of risk factors for cardiovascular disease and their associations with diet and physical activity in suburban Beijing, China. J Epidemiol. 2010; 20 (3): 237-243.

\section{How to cite this article:}

Shomad MBA, Rahman NAA, Rahman NIA, Haque M. The Prevalence of Cardiovascular Disease Risk Factors among Students of International Islamic Universiti Malaysia, Kuantan Campus. J App Pharm Sci, 2016; 6 (03): 051-057. 